\title{
Alternative Production Processes of Calcium Silicate Phases of Portland Cement: A Review
}

\author{
Natalia Betancur-Granados*, Jorge I Tobón and Oscar Jaime Restrepo-Baena \\ Materials and Minerals Department, Universidad Nacional de Colombia, USA
}

Submission: May 6, 2018; Published: June 15, 2018

*Corresponding author: Natalia Betancur-Granados, Materials and Minerals Department. Cement and Construction Materials Research Group, Universidad Nacional de Colombia, Calle 59A No 63 - 20, Medellín 050036, Natalia Betancur-Granados, Colombia, USA, Tel: 0057 3004814710;

E-mail: nbetancurg@unal.edu.co

\begin{abstract}
Calcium silicates production by alternative methods to solid state reaction method has gained importance because of the possibility to obtain materials with higher performance and less energy consumption than the traditional process. Exploring the application of non-conventional methods for the production of cementitious materials is an interesting alternative to produce materials with high performance, as nanoparticles, which are expected to permit high reactivity of the phases. The alternative methods require more studies allowing to understand the individually and the combine effects of synthesis processes conditions over the particles properties.
\end{abstract}

Keywords: Synthesis; Alternative methods; Calcium silicates; Clinker; Portland cement; Pure cement phases

Abbreviations: OPC: Ordinary Portland Cement; T: Triclinic; M: Monoclinic; R: Rhombohedral; SCS: Solution Combustion Synthesis; FSP: Flame Spray Pyrolysis; SPS: Spark Plasma Sintering; MOCVD: Metallorganic Chemical Vapor Deposition

\section{Introduction}

Global demand of cement is increasing year by year in a factor of 25; therefore, greenhouse gas emissions from this industry are growing in significant amounts. Nowadays, $\mathrm{CO}_{2}$ emissions for cement production correspond almost to $5-8 \%$ worldwide, which is a motivation to find solutions to reduce the environmental impact. Some ways to attack this problem are applying new technologies, improving current technology, and using alternative cement substitutes and alternative fuels [1].

Ordinary Portland Cement (OPC) is a popular construction material traditionally obtained by the combination of limestone and clays. The main component formed during its fabrication is the clinker, which is composed by four main phases, alite $\left(\mathrm{Ca}_{3} \mathrm{SiO}_{5}\right.$ or $\mathrm{C}_{3} \mathrm{~S}$ ), belite $\left(\mathrm{Ca}_{2} \mathrm{SiO}_{4}\right.$ or $\left.\mathrm{C}_{2} \mathrm{~S}\right)$, celite $\left(\mathrm{Ca}_{3} \mathrm{Al}_{2} \mathrm{O}_{6}\right.$ or $\left.\mathrm{C}_{3} \mathrm{~A}\right)$ and ferrite $\left(\mathrm{Ca}_{4} \mathrm{Al}_{2} \mathrm{Fe}_{2} \mathrm{O}_{10}\right.$ or $\left.\mathrm{C}_{4} \mathrm{AF}\right)$. The calcium silicate phases, alite and belite, are responsible of the development of mechanical properties, such as compressive strength in construction structures, while aluminate phases, celite and ferrite, play a role in the setting time of cement and durability of concrete [2,3].

Pure cement phases with nanometric size have been obtained by non-conventional methods such as Pechini, sol-gel and selfpropagating combustion, which showed good results to the formation of the cement matrix. The first work in the study of pure cement phases was done by R. Roy and Oyefebesi in 1977 using the sol-gel method [4]. Since then, different research have been done in the study of the process effects on the formation of cement polymorphs and their reactivity, considering the anhydrous and hydrated compounds [5-12].

The study of cementitious materials, such as pure cement phases, allows the understanding of phenomena related to hydration chemical reactions of clinker, enabling the improvement of cement properties in macroscopic systems and providing more information about the influence of atomic position on the level of reactivity of the structure in single crystal systems $[3,13]$.

Production and performance improvements of cementitious materials allow the reduction of energy consumption and mitigate the negative impacts of cement industry. Most strategies are focus onthe improvement of clinker performance and alternative processes for its production. Hence, this paper shows a review of research focused on the synthesis of cementitious phases, especially the calcium silicates alite and belite, through nonconventional methods.

\section{Calcium Silicate Phases of Portland Cement}

Calcium silicates, corresponding to approximately $75 \%$ of the Portland cement, are a group of compounds formed by complex reactions between calcium and silicon oxides, with or without the presence of foreign ions. The crystal structure of calcium silicate compounds change with the starting stoichiometry and 


\section{Civil Engineering Research Journal}

temperature, giving rise to the formation of polymorphs, which show different features as hydration behavior [14].

\section{Alite}

Tricalcium silicate, named alite $\left(\mathrm{C}_{3} \mathrm{~S}\right)$, is the main active component in clinker, which has high hydration rates and is the responsible of strength development during ages up to 28 days [15-17]. This compound has a nesosilicate structure, which means that is composed by the binding of a silicon atom with four oxygen atoms to form a tetrahedral structure by covalent bonds, $\left[\mathrm{SiO}_{4}\right]^{4-}$, and it could have ionic bonds with metals as calcium, magnesium, iron, among others [18]. Alite presents a large grade of polymorphism, which depends mainly of temperature and impurities, having an effect on the silicate tetrahedral orientations. The reported structures are in triclinic (T), monoclinic (M) and rhombohedral (R) lattice systems, which have reversible transformations. During the cooling process to room temperature, the pure compound $\mathrm{TI}$ is obtained at $620^{\circ} \mathrm{C}$ corresponding to the triclinic system, other transformations for monoclinic system occur at $980{ }^{\circ} \mathrm{C}$ and finally at $1070{ }^{\circ} \mathrm{C}$ for rhombohedral (Figure 1 ), where the last one presents the smallest unit cell and the highest symmetry [19-22].

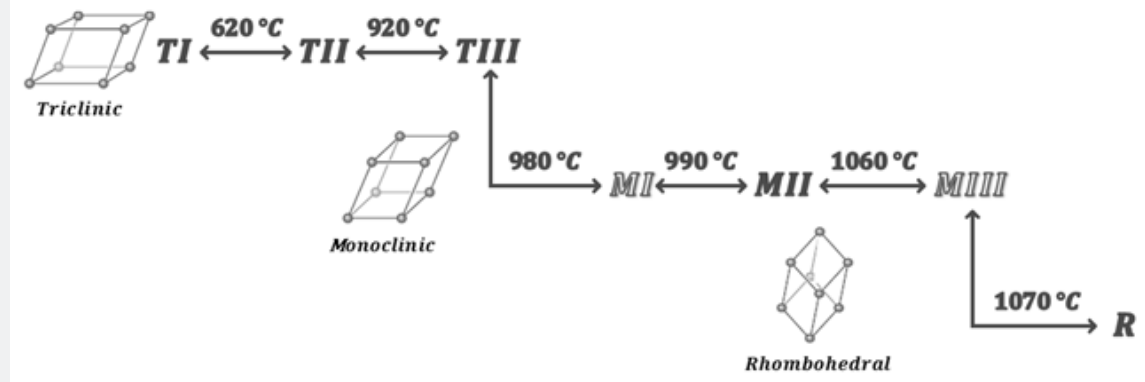

Figure 1: Tricalcium silicate polymorphic transformations.

The polymorphic structures are T1, T2, T3, M1, M2, M3 and R. Polymorphs M1 and M3 are commonly found in clinker due to the incorporation of foreign ions as $\mathrm{Mg}^{2+}$ and could be identify by birefringence measurements while the polymorph $\mathrm{T} 2$ is rarely found; at room temperature pure tricalcium silicate present the triclinic structure $\mathrm{T} 1[3,18,20,23]$. The knowledge of crystal structure of alite polymorphs is a complex topic and still requires more studies. The crystal structure of the polymorphs T1, M3 and $\mathrm{R}$ have been determinated and there are models for T2, T3, M1 and $\mathrm{R}$, however, there is not even a model for M2 [18]. To study the polymorphs, researchers have used impure alite by the addition of foreign ions as zinc, phosphorus, aluminum, magnesium and others, getting different stabilization effects depending of the amount and type of foreign ion [18,23]. Also, the models used to get information about the crystal structure of polymorphs, take into account the shape of the unit cell and the space group, based on metric relation and the deformation of unit cell, considering vector directions and planes [20]. For example, using XRD data of polymorphs, Regourd et al. [24], studied the evolution of the cell parameters. They found the existence of an average unit cell or superstructures. Based on it, they could propose structures for triclinic and monoclinic polymorphs, considering the displacements of calcium atoms and the orientations of siliconoxygen tetrahedral [20-22,25].

\section{Belite}

Dicalcium silicate or belite $\left(\mathrm{C}_{2} \mathrm{~S}\right)$ is a clinker phase that provides slow reactivity in early ages with a slow setting time, however this compound plays an important role in the final compressive strength of the structures. Also, the presence of $\mathrm{C}_{2} \mathrm{~S}$ in cements improves the resistance to chemical attack, drying shrinkage and, as a consequence allows the elaboration of most durable of the Portland cements [26]. The melting point of this phase is $2130{ }^{\circ} \mathrm{C}$. From room temperature until melting point, belite presents several phase transformations, giving place to five polymorphs, ( $\alpha, \beta$ and $\gamma$ families) where the most common polymorph is $\beta-\mathrm{C}_{2}$ S.The $\alpha$ and $\beta$ families of polymorphs present a close crystal structure, while $\gamma$ polymorph is noticeably different. The polymorph $\gamma-\mathrm{C}_{2} \mathrm{~S}$ is not desired during the clinker formation, since it is the only phase that is non-reactive with water $[3,27]$. Figure 2 shows the polymorphic transformations of dicalcium silicate $[17,28]$.

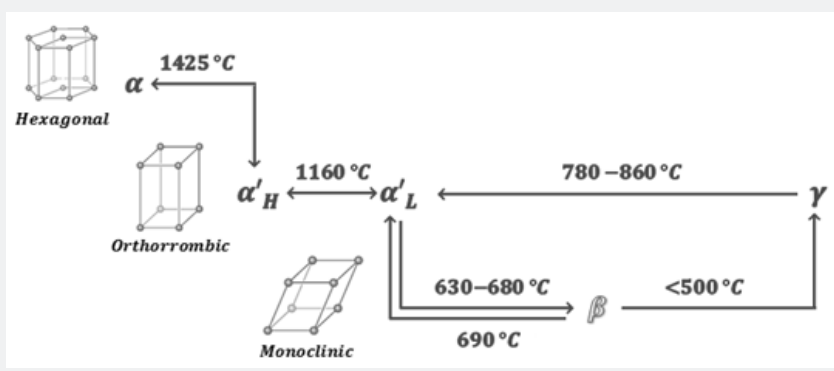

Figure 2: Dicalcium silicate polymorphic transformations. 


\section{Civil Engineering Research Journal}

To produce better cementitious materials with lower footprint, reactivity of belite has been strongly studied during the last decades [18]. Research show two polymorphs with higher reactivity than alite, with the same composition of the others polymorphs. One of them, called $\mathrm{x}-\mathrm{C}_{2} \mathrm{~S}$, presents a different crystal structure in comparison with the other polymorphs, and has the presence of "tunnels" which could be the responsible of the high reactivity [18]. Similarly than alite, $\mathrm{C}_{2} \mathrm{~S}$ allows the incorporation of foreign ions in order to modify its activity. Foreign ions as phosphorous, aluminum, boron, sulfur, etc., have been studied to know the effect on the reactivity of the impure belite. In the case of sulfur,e.g., some investigations showed an increase in the hydraulic activity, while others report a decrease in the reactivity [18].

\section{Traditional Synthesis Process}

Cementitious phases have been commonly made by solid state reaction or fusion process. The main advantage of this method is the simplicity of the process, however, it presents some important difficulties as the high energy consumption and the slow diffusion process which leads to non-homogeneous phases $[5,29]$.

This decomposition method presents highly complex reactions, since physical and chemical processes as solid state decomposition, gas-solid reactions, desorption, diffusion, sublimations and others, are involved simultaneously. The presence of crystal defects is fundamental because the solid reactivity increase as a consequence of these high energy regions [30,31]. Therefore, the chemical transformations take place in restricted zones of the solid, generating local reactivity areas where the mobility of the ions and molecules controls the reactivity [32-34].

Research about the production of simple cement systems by solid state reaction method were done by Hasen (1928), Carlson (1930), Philips (1959) and Welch (1977), where are reported the formation and decomposition processes of tricalcium and dicalcium silicate, the stability of chemical systems and the thermodynamic behavior of pure phases of cement [35-38]. Looking for improvement of the synthesis of powders by solid state reactions, it has been used strategies as the addition of mineralizers, wet milling and additional energy resources as microwaves. F. A. Rodrigues et al., [39], evaluated the effect of different compositions of barium additions in the formation of dicalcium silicate, using wet milling and ultrasonic bath to improve the precursors interaction, obtaining be lite at $800{ }^{\circ} \mathrm{C}$ without the presence of residual CaO. Similarly, Quéméneur et al., Shizong Long et al., and Haoxuan Li et al., applied microwaves during the sintering to improve the interaction between the solid starting materials and decrease the temperature and duration of the process, achieving temperature reductions close to $100{ }^{\circ} \mathrm{C}$ [40-44].

Even when cement phases are successfully obtained by solid state reactions, the high energy demand and $\mathrm{CO}_{2}$ emissions resulting during this process, lead researchers to propose new alternatives. To overcome these problems, alternative batch methods as Pechini, sol-gel, solution combustion, have been used and to a lesser extent continuous processes as aerosol methodologies, as it will be shown below.

\section{Alternative Synthesis Processes}

Materials science and nanotechnology advances have had a strong influence in the material synthesis processes. The use of nanoscale systems in cement industry allows to develop a fundamental understanding which could be transferred to macroscopic systems, and at the same time, allows the development of stronger, durable and environmentally friendly materials by use of novel synthesis methods [45].

Cement pure phases have been obtained by non-conventional methods in nanometer size. Methods as Pechini and sol-gel show good results, since hydration products are part of the synthesis process, allowing the formation of $\mathrm{C}-\mathrm{S}-\mathrm{H}$ gel, which gives place to cement matrix. Sol-gel has been one of the most widely used alternative methods, which can be performed by gelation of a solution of colloidal particles, hydrolysis and polycondensation of alkoxides or nitrates followed by a hypercritical drying of the gel or by hydrolysis and polycondensation of an alkoxide followed by curing and drying of gel at atmospheric temperature [46]. The first work in sol-gel was developed for R. Roy and Oyefebesi in 1954, giving rise to the study of pure phases of cement made by alternative methods. They studied the mechanical behavior of highly reactive belite showing increases of around 20MPa in compressive strength compared to powders produced by hightemperature sintering, since this method starts from precursors in solution or colloidal form allowing a close interaction between the ions and, as a consequence, the production of particles with high surface area and a defined composition [4]. Researchers as Stephan et al. [5], Anikó Meiszterics [6,7] and R. Chrysafi et al. [8] evaluated process parameters as $\mathrm{pH}$, concentration and temperature, over the specific surface area and their effects on the reactivity and G. Laudisio y F. Branda [47] studied the crystallization behavior of $3 \mathrm{CaO} .2 \mathrm{SiO}_{2}$ during the synthesis. Other research focused in biomaterials presented by Zhougru Gou et al. [48,49], Wenyuan Zhao et al. [50,51] and Chun-Cheng Chen et al. [52], used dicalcium silicate polymorphs and tricalcium silicate to study the behavior during the sintering process, mechanical properties and in vitro bioactivity using simulated body fluid (SBF).Additionally by Pechini method, I. Nettleship et al. [9] and Seong-Hyeon Hong et al. [10], prepared different polymorphs of dicalcium silicate by changing the process temperature and, in a similar way, they evaluated the products reactivity [53]. I. Nettleship et al. studied the $\beta \rightarrow \gamma$ transformation to $\mathrm{Ca}_{2} \mathrm{SiO}_{4}$ while Seong-Hyeon Hong et al. prepared the $\alpha^{\prime} \mathrm{L}-\mathrm{Ca}_{2} \mathrm{SiO}_{4}, \beta-\mathrm{Ca}_{2} \mathrm{SiO}_{4}$ and $\gamma-\mathrm{Ca}_{2} \mathrm{SiO}_{4}$ polymorphs by changing the process conditions. Both studies conclude about the increment in the reactivity because of the increment in the specific surface area. Besides, calcium aluminate phases related with setting time in Portland cement 
systems have also been done by alternative methods. A. Gaki et al. [2] and G. Voicu et al. [13] prepared calcium aluminate phases using Pechini method while D. A. Fumo et al, [53] and A. CüneytTas et al. [11] prepared the same family of compounds by a close methodology called solution combustion synthesis (SCS) starting from metal nitrates and urea as fuel, analyzing the relation oxidants/fuel and decreasing considerably the synthesis temperature [54].

During self-combustion or solution combustion synthesis, a redox reaction is produced, heating a solution containing metal nitrates, $\mathrm{pH}$ stabilizers and a fuel up to the auto ignition temperature, resulting in a quick reaction in a self-produced flame. Researchers as Xiang-Hui Huang et al. [11] and Restrepo et al. $[12,55]$, prepared $\beta-\mathrm{Ca}_{2} \mathrm{SiO}_{4}$ using colloidal $\mathrm{SiO}_{2}$ and calcium nitrate as precursors and, glycine, citric acid and other organic compounds as fuels, resulting in the formation of products with different reactivity rates because of the changes in the specific surface area of the powders which is influenced by the energy given by the fuel. This method allows the production of calcium silicates without hydrate products in the structure, but when it comes into contact with water, the reaction occurs resulting in the formation of C-S-H gel [12].

Hideki Ishida et al., [56], M. Georgescu et al., [57], LarbiKacimi et al., [58] and Nakshatra B. Singh et al., [26] prepared $\beta-\mathrm{Ca}_{2} \mathrm{SiO}_{4}$ by hydrothermal synthesis. These studies analyzed the influence of process conditions such as pressure, temperature, agitation, concentration and heating time, in the formation of highly reactive belite. Hideki Ishida's work studied the phase formation with temperature variations at atmospheric pressure similarly than LarbiKacimi but using fly ashes as starting materials instead of Hillebrandite as Ishida's work, while M. Georgescu used pressures of $1 \mathrm{~atm}$ and $16 \mathrm{~atm}$ at constant temperature. On the other hand, Nakshatra B. Singh's research considers both conditions, analyzing the influence of pressure and temperature.

As noticed above, mentioned methods such as Pechini, sol-gel, hydrothermal and self-combustion are batch processes, which often require later treatments as filtration, drying and calcination, making them less attractive to industrial applications $[59,60]$. Considering the high cement production volumes, it is necessary to propose alternative scalable manufacturing processes, whereby aerosol technologies have a great potential since they are continuous processes and can be easily taken to industrial production, allowing the production from $\mathrm{g} / \mathrm{h}$ to $\mathrm{kg} / \mathrm{h}$ without disturbing particles features [61,62].

In aerosol flame methods, the solution is subjected under an energetic resource which achieves high temperatures in few minutes, resulting in nanopowders formation. By flame spray pyrolysis (FSP), S.C. Halim shows the preparation of ultra-fast binding cement, preparing a typical clinker formulation. Results show a highly reactive material as a consequence of high surface area by the reduction of particle size in comparison with traditional clinker. However, mechanical properties showed unfavorable results due to high porosity in the cement blocks prepared to make measurements [63]. Furthermore, Tobias J. Brunner et al., prepared bioglasses and calcium phosphates cements changing the stoichiometry by addition of different cations. Bioactivity was evaluated for medical applications and strategies to control the setting rate of calcium phosphate phases were proposed by the manipulation of process conditions [64-66]. Hongbin Zhong et al., also evaluated the in vitro bioactivity of $\beta-\mathrm{Ca}_{2} \mathrm{SiO}_{4}$ made through spark plasma sintering (SPS) in a process with high heating rate, high pressure, high energy activity and short sintering time [67]. During this process, resulting powders show a bending strength ten times higher than conventional made materials as a consequence of the quick particles densification. Shekhar Nath et al., [68] evaluated apatite formation in $\beta-\mathrm{Ca}_{2} \mathrm{SiO}_{4}$ in powders made by metallorganic chemical vapor deposition (MOCVD), achieving the formation of apatite in the material surface after immersion in Hank's solution.

As shown above, several research have been proposed to overcome the problems observed in the traditional method, allowing the improvement of cementitious materials, however, most of the studied processes present strong limitations to scale up to industrial applications. Therefore, it is important to give attention to continuous processes such as aerosol flame methods. One of the most promising aerosol methodologies to powders production is flame spray pyrolysis method, which has been studied during the last decades to obtain nanopowders at high production level $[5,6]$. This method seems as an efficient process to obtain calcium silicate phases because the reaction takes place in a short time, giving as a result meta stable oxide phases. However, the effect of the process conditions over the products needs to be studied in each solvent-chemical precursors system, because each formulation has a specific combustion environment [6].

\section{Conclusion}

Polymorphs of calcium silicate phases and their hydration activity area broad topic that is strongly studied around the world. The wide amounts of variables make of this topic a complex research, which is why there is not a single answer to the phenomena that occurs in cement phases formation and hydration.

The use of alternative synthesis methods with control over the process conditions in the production of cementitious phases allows manipulation of products features, and therefore a better understanding of the crystal structure of the cement phases and the hydration mechanism to improve the properties of the cement. Alternative synthesis methods as Pechini, sol-gel and self-combustion are become important because of the possibility of reducing the energetic consumption process and produce nanoparticles with superior features than traditional powders. However, all of them are batch methods, which is a limitation to 


\section{Civil Engineering Research Journal}

scale-up the process. Therefore, it is important the implementation of continuous methods which allows the scale-up of the process.

\section{Acknowledgement}

The authors acknowledge to the Universidad Nacional de Colombia, Group of Cement and Construction Materials and Colciencias for their support to this research.

\section{Conflict of Interest}

Declare if any economic interest or any conflict of interest exists.

\section{References}

1. Kajaste R, Hurme M (2015) Cement industry greenhouse gas emissions - management options and abatement cost. J Clean Prod 112(5): 40414052 .

2. Gaki A, Chrysafi R, Kakali G (2007) Chemical synthesis of hydraulic calcium aluminate compounds using the Pechini technique. J Eur Ceram Soc 27(2-3): 1781-1784.

3. Wesselsky A, Jensen OM (2009) Synthesis of pure Portland cement phases. Cem Concr Res 39(11): 973-980.

4. Roy DM, Oyefesobi SO (1977) Preparation of Very Reactive Ca2SiO4 Powder. J Am Ceram Soc 60(3-4): 178-180.

5. Stephan D, Wilhelm P (2004) Synthesis of Pure Cementitious Phases by Sol-Gel Process as Precursor. Zeitschrift für Anorg und Allg Chemie 630(10): 1477-1483.

6. Meiszterics A, Sinkó K (2008) Sol-gel derived calcium silicate ceramics. Colloids Surfaces A Physicochem. Eng Asp 319(1-3): 143-148.

7. Meiszterics A, et al. (2010) Structural Characterization of Gel-Derived Calcium Silicate Systems. J Phys Chem 114: 10403-10411.

8. Chrysafi R, Perraki T, Kakali G (2007) Sol-gel preparation of 2CaO.SiO2. J Eur Ceram Soc 27(2-3): 1707-1710.

9. Nettleship I, Shull JL, Kriven WM (1993) Chemical preparation and phase stability of $\mathrm{Ca} 2 \mathrm{SiO} 4$ and $\mathrm{Sr} 2 \mathrm{SiO} 4$ powders. J Eur Ceram Soc 11(4): 291-298.

10. Hong SH, Young JF (1999) Hydration kinetics and phase stability of dicalcium silicate synthesized by the Pechini process. Am Ceram Soc 82(7): 1681-1686.

11. Huang XH, Chang J (2007) Low-temperature synthesis of nanocrystalline $\beta$-dicalcium silicate with high specific surface area. J Nanoparticle Res 9(6): 1195-1200.

12. Restrepo JC (2015) Síntesis de silicatos cálcicos hidraulicamnete activos producidos a partir de métodos químicos de combustion. Universidad Nacional de Colombia.

13. Voicu G, Ghiţulică CD, Andronescu E (2012) Modified Pechini synthesis of tricalcium aluminate powder. Mater Charact 73: 89-95.

14. Nicoleau L, Nonat A, Perrey D (2013) The di- and tricalcium silicate dissolutions. Cem Concr Res 47: 14-30.

15. Arías Jaramillo YP (2013) Incidencia de la temperatura ambiente en la formación de compuestos cementantes mediante la activación alcalina de ceniza de carbon. Universidad Nacional de Colombia.

16. Li X, Shen X, Tang M, Li X (2014) Stability of tricalcium silicate and other primary phases in portland cement clinker. Ind Eng Chem Res 53(5): 1954-1964.

17. Taylor HFW (1997) Cement Chemistry.
18. Ludwig HM, Zhang W (2015) Research review of cement clinker chemistry. Cem Concr Res 78: 24-37.

19. Bazzoni A, Ma S, Wang Q, Shen X, Cantoni M (2014) The effect of Magnesium and Zinc Ions on the Hydration kinetics of C3S. J Am Ceram Soc 97(11): 3684-3693.

20. de Noirfontaine MN, Dunstetter F, Courtial M, Gasecki G, Signes-Frehel M (2006) Polymorphism of tricalcium silicate, the major compound of Portland cement clinker. Cem Concr Res 36(1): 54-64.

21. Urabe K, Shirakami T, Iwashima M (2000) Superstructure in a triclinic phase of tricalcium silicate. J Am Ceram Soc 83(5): 1253-1258.

22. Dunstetter F, De Noirfontaine MN, Courtial M (2006) Polymorphism of tricalcium silicate, the major compound of Portland cement clinker: 1. Structural data: Review and unified analysis. Cem Concr Res 36(1): 39-53.

23. De la Torre ÁG, De Vera RN, Cuberos aJM, Aranda MaG (2008) Crystal structure of low magnesium-content alite: Application to Rietveld quantitative phase analysis. Cem Concr Res 38(11): 1261-1269.

24. Bigaré M, et al (1967) Polymorphism of Tricalcium Silicate and Its Solid Solutions. J Am Ceram Soc 50(11): 609-619.

25. Peterson VK, Hunter Ba, Ray A (2004) Tricalcium Silicate T1 and T2 Polymorphic Investigations: Rietveld Refinement at Various Temperatures Using Synchrotron Powder Diffraction. J Am Ceram Soc 87(9): 1625-1634.

26. Singh NB, Rai S, Singh N (2002) Highly Reactive B-Dicalcium Silicate. J Am Ceram Soc 85(9): 2171-2176.

27. Yamnova NA, Zubkova NV, Eremin NN, Zadov AE, Gazeev VM (2011) Crystal structure of larnite $\beta$-Ca2SiO4 and specific features of polymorphic transitions in dicalcium orthosilicate. Crystallogr. Reports 56(2): 210-220.

28. Cuesta-García AM (2015) Preparation and hydration of model ecocement phases. Characterization by diffraction and cognate methods. Universidad de Málaga.

29. Restrepo JC, Chavarriaga A, Restrepo OJ, Tobón JI (2015) Synthesis of Hydraulically Active Calcium Silicates Produced by Combustion Methods. MRS Proc 1768, p. imrc2014-6d-008, 2015.

30. Deb P (2014) Kinetics of Heterogeneous Solid State Processes. In Kinetics of Heterogeneous Solid State Processes, Springer, pp. 13-18.

31. Buchete NV, Santosh K Upadhyay (2006) Chemical Kinetics and Reaction Dynamics. J Stat Phys 129(2): 407-408.

32. Calbo J (2003) Desarrollo de ecopigmentos negros de espinela dopada alternativos a los ferritos tradicionales mediante presión y procesados sol-gel. Universitat Jaume I de Castelló.

33. Betancur N (2014) Síntesis de pigmentos ceramicos a partir de cromitas de estructura tipo espinela por el método no convencional de pirólisis de aerosol con llama con alimentación líquida. Universidad Nacional de Colombia.

34. Bamford CH, Tipper CFH (1980) Reactions in the Solid State - Google Books. In Comprehensive chemical kinetics, Elsevier, p. 339.

35. Welch JH, Gutt W (1959) Tricalcium Silicate and Its Stability Within the System CaO-SiO2. J Am Ceram Soc 41(1): 11-15.

36. Carlson ET (1930) The Decomposition of Tricalcium Silicate. Bur Stand J Res 33(8): 78-79.

37. Phillips B, Muan A (1959) Phase Equilibria in the System CaO-Iron Oxide-SiO2, in Air. J Am Ceram Soc 42(9): 413-423.

38. Hasen WC (1928) Further studies on portland cement compounds by the X-Ray diffraction method. Bur Stand J Res 11(2). 


\section{Civil Engineering Research Journal}

39. Rodrigues FA (2003) Synthesis of chemically and structurally modified dicalcium silicate. Cem Concr Res 33(6): 823-827.

40. Quéméneur L, Choisnet J, Raveau B, Thiebaut JM, Roussy G (1983) Microwave Clinkering with a Grooved Resonant Applicator. J Am Ceram Soc 66(12): 855-859.

41. Li H, Agrawal DK, Cheng J, Silsbee MR (2001) Microwave sintering of sulphoaluminate cement with utility wastes. Cem Concr Res 31(9): 1257-1261.

42. Li H, Agrawal DK, Cheng J, Silsbee MR (1999) Formation and hydration of C3S prepared by microwave and conventional sintering. Cem Concr Res 29(10): 1611-1617.

43. Long S, Yan C, Dong J (2002) Microwave-promoted burning of Portland cement clinker. Cem Concr Res 32(1): 17-21.

44. Kacimi L, Simon-Masseron a, Ghomari a, Derriche Z (2006) Reduction of clinkerization temperature by using phosphogypsum. J Hazard Mater 137(1): 129-137.

45. Constantinides G (2013) Nanoscience and nanoengineering of cementbased materials. Nanotechnol. Eco-Efficient Constr, p. 9-37a.

46. Hench LL, West JK (1990) The sol-gel process. Chem Rev 90(1): 33-72.

47. Laudisio G, Branda F (2001) Sol-gel synthesis and crystallisation of $3 \mathrm{CaO} \bullet 2 \mathrm{SiO} 2$ glassy powders. Thermochim. Acta 370(1-2): 119-124.

48. Gou Z, Chang J (2004) Synthesis and in vitro bioactivity of dicalcium silicate powders. J Eur Ceram Soc 24(1): 93-99.

49. Gou Z, Chang J, Zhai W (2005) Preparation and characterization of novel bioactive dicalcium silicate ceramics. J Eur Ceram Soc 25(9): $1507-1514$

50. Zhao W, Chang J (2004) Sol-gel synthesis and in vitro bioactivity of tricalcium silicate powders. Mater Lett 58(19): 2350-2353.

51. Zhao W, Wang J, Zhai W, Wang Z, Chang J (2005) The self-setting properties and in vitro bioactivity of tricalcium silicate. Biomaterials 26(31): 6113-6121.

52. Chen CC, Ho CC, Lin SY, Ding SJ (2015) Green synthesis of calcium silicate bioceramic powders. Ceram Int 41(4): 5445-5453.

53. Fumo Da, Morelli MR, Segadães AM (1996) Combustion synthesis of calcium aluminates. Mater Res Bull 31(10): 1243-1255.

54. Tas AC (1998) Chemical Preparation of the Binary Compounds in the Calcia-Alumina System by Self-Propagating Combustion Synthesis. J Am Ceram Soc 81(11): 2853-2863.
55. Restrepo JC, Chavarriaga A, Restrepo 0J, Tobón JI (2015) Synthesis of Hydraulically Active Calcium Silicates Produced by Combustion Methods. MRS Proc 1768, p. imrc2014-6d-008.

56. Ishida H, Mabuchi K, Sasaki K (1992) Low-Temperature Synthesis. no. 1, 1992.

57. Georgescu M, Tipan J, Badanoiu A, Crisan D, Dragan I (2000) Highly reactive dicalcium silicate synthesized by hydrothermal processing Cem Concr Compos 22(5): 315-319.

58. Kacimi L, Cyr M, Clastres P (2010) Synthesis of alfa-C2S cement from fly-ash using the hydrothermal method at low temperature and atmospheric pressure. J Hazard Mater 181(1-3): 593-601.

59. Strobel R, Alfons A, Pratsinis SE (2006) Aerosol flame synthesis of catalysts. Adv Powder Technol 17(5): 457-480.

60. Halim SC, Stark WJ, Zurich ETH (2006) In Situ Preparation of Nano Portland Cement Via Flame Spray Pyrolysis: Processing, Characterization and Mechanical Properties. TMS 2006 1356(2002): $5184 \mathrm{p}$.

61. Qin X, Ju Y, Bernhard S, Yao N (2007) Europium-doped yttrium silicate nanophosphors prepared by flame synthesis. Mater Res Bull 42(8): 1440-1449.

62. Gröhn AJ, Pratsinis SE, Wegner K (2012) Fluid-particle dynamics during combustion spray aerosol synthesis of ZrO 2. Chem Eng J 191: 491-502.

63. Halim SC, Brunner TJ, Grass RN, Bohner M, Stark WJ (2007) Preparation of an ultra fast binding cement from calcium silicate-based mixed oxide nanoparticles. Nanotechnology 18(39): 395701 p.

64. Brunner TJ, Grass RN, Stark WJ (2006) Glass and bioglass nanopowders by flame synthesis. Chem Commun (Camb) 7(13): 1384-1386.

65. Brunner TJ, Grass RN, Bohner M, Stark WJ (2007) Effect of particle size, crystal phase and crystallinityon the reactivity of tricalcium phosphate cements for bone reconstruction. J Mater Chem 17(38): 4072 p.

66. Bohner M, Brunner TJ, Stark WJ (2008) Controlling the Reactivity of Calcium Phosphate Cements. Key Eng Mater 361-363: 295-298.

67.Zhong H, et al., (2011) Mechanical properties and bioactivity of $\beta$ - $\mathrm{Ca}_{2} \mathrm{SiO}_{4}$ ceramics synthesized by spark plasma sintering. Ceram Int 37(7): 2459-2465.

68. Nath S, Tu R, Goto T (2011) Apatite formation in Hanks' solution on $\beta-\mathrm{Ca}_{2} \mathrm{SiO}_{4}$ films prepared by MOCVD. Surf Coatings Technol 206(1): 172-177.

\section{Your next submission with Juniper Publishers will reach you the below assets}

- Quality Editorial service

- Swift Peer Review

- Reprints availability

- E-prints Service

- Manuscript Podcast for convenient understanding

- Global attainment for your research

- Manuscript accessibility in different formats

( Pdf, E-pub, Full Text, Audio)

- Unceasing customer service

Track the below URL for one-step submission https://juniperpublishers.com/online-submission.php 